\title{
Xenoxylon synecology and palaeoclimatic implications for the Mesozoic of Eurasia
}

Changhwan Oh, Marc Philippe, and Kyungsik Kim

Acta Palaeontologica Polonica 60 (1), 2015: 245-256 doi: http://dx.doi.org/10.4202/app.2012.0132

The distribution of fossil wood genera has been demonstrated to be an effective proxy for Mesozoic terrestrial climates. In this study, we investigated the phytocoenoses, which were associated with Xenoxylon confirmed to be a marker for a cool and/or wet climate in a boreal hemisphere (i.e., Xenoxylon -phytocoenoses) during the Mesozoic, using specimens of fossil wood. It was confirmed that Xenoxylon co-occurs more often with some wood genera than with others. For example, Protocedroxylon, a wood that is most likely related to the Pinaceae, is the genus most often associated with Xenoxylon-phytocoenoses. Although Taxodioxylon is also found in Xenoxylon-phytocoenoses, it is not found, however, as consistently as Protocedroxylon . The distribution and diversity of Xenoxylon-phytocoenoses changed throughout the Mesozoic. During the Late Triassic and Late Cretaceous, Xenoxylon -phytocoenoses had low diversity and were restricted to higher palaeolatitudes during the Late Cretaceous. However, during the Early to Middle Jurassic, Xenoxylon -phytocoenoses were distributed much farther south, while their diversity concomitantly increased sharply. From the Late Jurassic to the Early Cretaceous, the distribution of Xenoxylon-phytocoenoses moved northward in Europe and even more so in East Asia. The changes in the distribution of Xenoxylon -phytocoenoses are in agreement with changes in both global and regional climates. Our results also demonstrated that, within the Xenoxylon distribution range, the corresponding phytocoenoses were differentiated along a latitudinal gradient and according to the global climate change patterns during the Mesozoic.

Key words: Fossil wood, Xenoxylon-phytocoenoses, palaeoecology, palaeoclimate, Mesozoic, Eurasia.

Changhwan Oh [bluegaia@kopri.re.kr] Division of Polar Earth-System

Sciences, Korea Polar Research Institute, 26 Songdomirae-ro, Yeonsu-gu, Incheon, 406-840, Republic of Korea; Marc Philippe [marc.philippe@univ-lyon1.fr], Paléobotanique, Université Claude Bernard-Lyon 1 and UMR5276 of the CNRS, F69622, France; Kyungsik Kim [kksik@jbnu.ac.kr], Department of Life Sciences, Chonbuk National University, 570-752, Republic of Korea. 
This is an open-access article distributed under the terms of the Creative Commons Attribution License (for details please see creativecommons.org), which permits unrestricted use, distribution, and reproduction in any medium, provided the original author and source are credited.

FaF Full text $(527.5 \mathrm{kB})$ ।

FoF Supplementary file $(199.2 \mathrm{kB})$ 